\title{
Risk Assessment and Prediction of Heavy Metal Pollution in Groundwater and River Sediment: A Case Study of a Typical Agricultural Irrigation Area in Northeast China
}

\author{
Shuang Zhong, ${ }^{1}$ Hui Geng, ${ }^{2}$ Fengjun Zhang, ${ }^{1}$ Zhaoying Liu, \\ Tianye Wang, ${ }^{1}$ and Boyu Song ${ }^{3}$ \\ ${ }^{1}$ Key Lab of Groundwater Resources and Environment, Ministry of Education, Jilin University, Changchun 130021, China \\ ${ }^{2}$ Environmental Assessment Center of Jilin Province, Changchun 130022, China \\ ${ }^{3}$ Environmental Protection Research Institute of Light Industry, Beijing 100089, China
}

Correspondence should be addressed to Tianye Wang; wangtianyell@hotmail.com

Received 28 April 2015; Accepted 3 August 2015

Academic Editor: Jan Åke Jönsson

Copyright (C) 2015 Shuang Zhong et al. This is an open access article distributed under the Creative Commons Attribution License, which permits unrestricted use, distribution, and reproduction in any medium, provided the original work is properly cited.

\begin{abstract}
The areas with typical municipal sewage discharge river and irrigation water function were selected as study sites in northeast China. The samples from groundwater and river sediment in this area were collected for the concentrations and forms of heavy metals $(\mathrm{Cr}(\mathrm{VI}), \mathrm{Cd}, \mathrm{As}$, and $\mathrm{Pb})$ analysis. The risk assessment of heavy metal pollution was conducted based on single-factor pollution index $(I)$ and Nemerow pollution index (NI). The results showed that only one groundwater sampling site reached a polluted level of heavy metals. There was a high potential ecological risk of Cd on the N21-2 sampling site in river sediment. The morphological analysis results of heavy metals in sediment showed that the release of heavy metals can be inferred as one of the main pollution sources of groundwater. In addition, the changes in the concentration and migration scope of As were predicted by using the Groundwater Modeling System (GMS). The predicted results showed that As will migrate downstream in the next decade, and the changing trend of As polluted areas was changed with As content districts because of some pump wells downstream to form groundwater depression cone, which made the solute transfer upstream.
\end{abstract}

\section{Introduction}

Heavy metals pollution in water, soils, and sediment is increasingly serious in China along with the rapid industrialization and urbanization $[1,2]$. Heavy metals as a type of persistent toxic pollutants [3] are unbiodegradable in the environment. Thus, the residual heavy metals in environment are threatening human health and ecosecurity $[4,5]$. The main sources of heavy metals in the water are atmospheric precipitation, discharge of industrial wastewater and urban sewage, mineral mining, and infusion of surface runoff $[6,7]$. Heavy metals are insoluble in the receiving water [8], and the majority of them are transformed from the aqueous phase to the solid phase and finally deposit in the sediment [9]. Due to this process, the contents of heavy metals in sediments were higher than those in aqueous phase; hence, that can be regarded as the accumulation library of heavy metals [10]. However, the heavy metals in the sediments can be released into the environment again [11], causing secondary pollution of the water [12] and chronically damaging the ecoenvironment $[13,14]$. The heavy metals as nondegradable toxic substances in the water [15] can be enriched via food chains from low- to high-level organisms [16]. Such enrichment leads to direct or indirect accumulation of heavy metals in human body, causing chronic poisoning and threatening human health or even life $[5,17,18]$.

The rapid economic development in northeast China has led to the quick increase of urban water demand and the expanding discharge of industrial wastewater and sewage, polluting the water system there severely. 
This paper aims to investigate the heavy metal pollution in groundwater and the sediments, and the spatial distribution characterization of the heavy metals in water system. The risks of heavy metal pollution in groundwater and the degrees and potential ecological risks of heavy metal pollution in sediments were assessed. The migration scope of As in water system was predicted by using the Groundwater Modeling System (GMS).

\section{Sample Collection and Measurement}

The study area was located south of northeast China. The study area was dominated by croplands along the river, and the elevation (mean 45-50 m) generally declined from northeast to southwest. Most of the study areas were covered by quaternary loose deposits. The river water runs from northeast to southwest.

Totally 33 groundwater sampling sites were distributed along the water flow direction of the river. Totally 12 sampling sites of sediment were distributed from $123^{\circ} 10^{\prime}$ to $123^{\circ} 28^{\prime} \mathrm{E}$, with reference to the sampling sites of groundwater. The sediment at varying depth was stratified and sampled (31 samples). The distribution of the sampling sites is showed in Figure 1.

$\mathrm{Cr}$, As, $\mathrm{Cd}$, and $\mathrm{Pb}$ were selected as monitoring factors based on the historical research data of environment pollution in the study area as well as the tasks of this study. Water samples were filtered through a $0.45 \mu \mathrm{m}$ cellulose acetate membrane before measurement. Samples of sediments were dried in an oven at $105^{\circ} \mathrm{C}$ for $24 \mathrm{~h}$ and the samples were microwave digested with nitric acid, hydrochloric acid, hydrofluoric acid, and hydrogen peroxide before determination, as described in a previous study [19]. The contents of heavy metals $(\mathrm{Cr}(\mathrm{VI})$, As, $\mathrm{Cd}$, and $\mathrm{Pb}$ ) in groundwater samples and in sediment samples digested were measured using an inductively coupled plasma mass spectrometer (ICPMS). Analytical quality control included analysis of reagent blank, sample blank, reference material, and three parallel samples.

\section{Risk Assessment of Groundwater Pollution}

3.1. Heavy Metal Pollution in Groundwater. The content distributions of $\mathrm{Cr}(\mathrm{VI})$, As, $\mathrm{Cd}$, and $\mathrm{Pb}$ in groundwater were plotted in Figure 2 using ArcGIS according to the test results. $\mathrm{Cr}(\mathrm{VI}), \mathrm{As}, \mathrm{Cd}$, and $\mathrm{Pb}$ pollution in groundwater was assessed on basis of Chinese National Quality Standard for Groundwater (GB/T 14848-93).

Clearly, the As, $\mathrm{Cr}(\mathrm{VI})$, and Cd contents in groundwater did not exceed the thresholds in Sanitary Standard for Drinking Water (GB 5749-2006), and the contents of heavy metals in most sites met class I in GB/T 14848-93 (Figure 2). However, the $\mathrm{Pb}$ contents in some sampling sites exceeded the thresholds in the above two standards.

\subsection{Risk Assessment of Heavy Metal Pollution in Groundwater.}

Two kinds of risk assessment models of heavy metal pollution degree were used to evaluate the heavy metal pollution in the groundwater in the study area.
TABLE 1: Classification of NI.

\begin{tabular}{lcc}
\hline Class & Pollution degree & NI \\
\hline 0 & No pollution & $\leq 0.5$ \\
1 & Clean & $0.5-0.7$ \\
2 & Warm & $0.7-1.0$ \\
3 & Polluted & $1.0-2.0$ \\
4 & Medium pollution & $2.0-3.0$ \\
5 & Severe pollution & $>3.0$ \\
\hline
\end{tabular}

3.2.1. Single-Factor Pollution Index (I). Single-factor pollution index $(I)$ is used to assess how a single heavy metal pollutes groundwater at a sampling site:

$$
I_{i}=\frac{C_{i}}{S_{i}}
$$

where $C_{i}$ is the measured content of pollutant $i$ in surface water $\left(\mu \mathrm{m} \cdot \mathrm{L}^{-1}\right)$ and $S_{i}$ is the evaluation standard of pollutant $i$ in surface water $\left(\mu \mathrm{m} \cdot \mathrm{L}^{-1}\right)$. When $I_{i}$ is $>1$, the content of that heavy metal exceeds the standard [20].

The results of single-factor pollution index of heavy metals in groundwater in the study areas are showed in Figure 3 using the class II standards in GB/T 14848-93. The Is of $\mathrm{Cd}$ at sites 10 and 17 were $>1$, indicating $\mathrm{Cd}$ contents exceeded the standard. The $\mathrm{Pb}$ contents at sites 18 and 28 also exceeded the standard. The Is of Cr(VI) and As did not exceed 1 , indicating the contents of these two heavy metals met the class II standards in GB/T 14848-93.

3.2.2. Nemerow Pollution Index. Nemerow pollution index (NI) is used to assess how several heavy metals pollute groundwater at a sampling site. This index considers the mean and maximum values of single-factor pollution index and highlights the pollutants with high pollution degrees. It is expressed as

$$
\mathrm{NI}=\left(\frac{\left[(1 / n) \sum\left(C_{i} / S_{i}\right)\right]^{2}+\left[\max \left(C_{i} / S_{i}\right)\right]^{2}}{2}\right)^{1 / 2},
$$

where $n$ is the number of indices; $C_{i}$ is the measured content of heavy metal $i ; S_{i}$ is the standard value. The heavy metal pollution in groundwater is divided by NI into 6 degrees [21] (Table 1).

The pollution degree and pollution level of heavy metals in groundwater were assessed with NI.

The heavy metal pollution was evaluated using class II standard in GB/T 14848-93. The NIs of heavy metals in groundwater in the study area are showed in Figure 4 . The NI at site 28 exceeded the standard; the NIs at sites 10,17 , and 18 were at warming level. The NIs at other sites were all at clean or no-pollution level.

3.3. Prediction of Long-Term Risks of Groundwater Pollution. The solute transport of As was simulated by using GMS with the above models and the results, under the natural state 


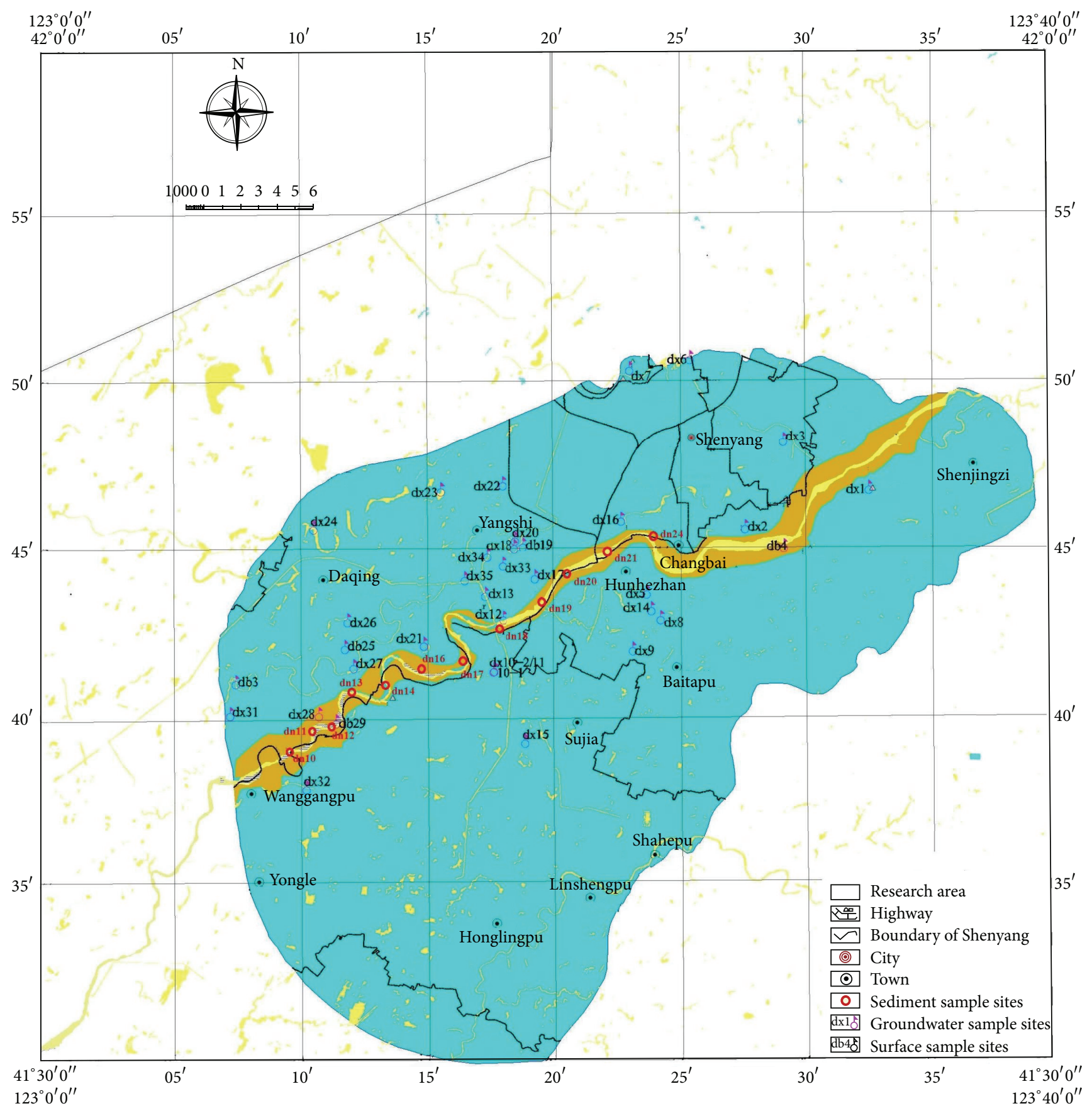

FIGURE 1: The distribution of the groundwater and sediment sampling sites.

without adding any external factors such as anthropogenic impact. The forms and distribution of pollution halo were characterized and the contents of specific pollutants in groundwater were predicted.

\subsubsection{Simulation of Solute Transport under Initial Conditions.} The solute transport was simulated by using the measured As contents as initial conditions without considering other pollution sources. The simulated As transport at different time periods in the study area is illustrated in Figure 5. The distribution area of As at different concentration ranges in different years was calculated by using the ArcGIS software.

The simulated results showed that the As polluted area was $286.28 \mathrm{~km}^{2}$ in the west of the study area and $98.36 \mathrm{~km}^{2}$ in the east of the study area at the moment, which indicated the main polluted area was in the downstream of the Hun River. We will discuss the west part mainly. The polluted areas were divided into five districts according to the As 


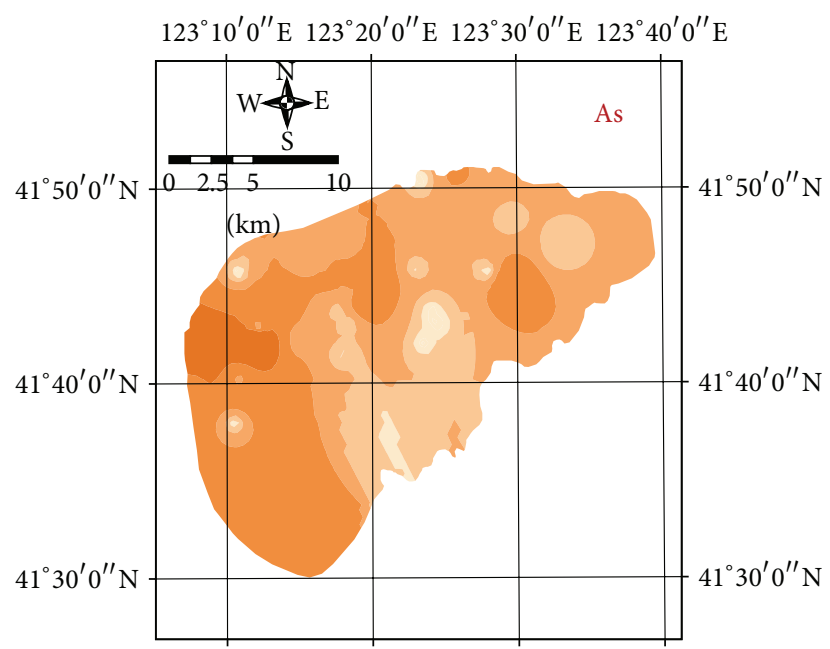

$123^{\circ} 10^{\prime} 0^{\prime \prime} \mathrm{E} 123^{\circ} 20^{\prime} 0^{\prime \prime} \mathrm{E} 123^{\circ} 30^{\prime} 0^{\prime \prime} \mathrm{E} 123^{\circ} 40^{\prime} 0^{\prime \prime} \mathrm{E}$

Concentration (ppb)

$0.000725-0.071313$

$0.071314-0.202355$

$0.202356-0.572866$

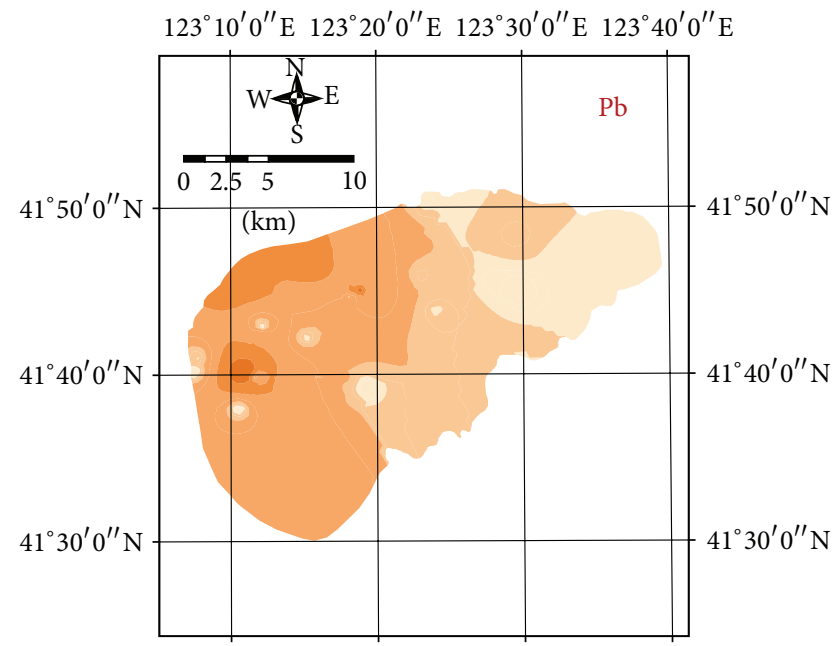

$123^{\circ} 10^{\prime} 0^{\prime \prime} \mathrm{E} 123^{\circ} 20^{\prime} 0^{\prime \prime} \mathrm{E} 123^{\circ} 30^{\prime} 0^{\prime \prime} \mathrm{E} 123^{\circ} 40^{\prime} 0^{\prime \prime} \mathrm{E}$

Concentration (ppb)

$0.159777-0.339941$

$0.339942-0.848101$

$0.848102-3.264031$

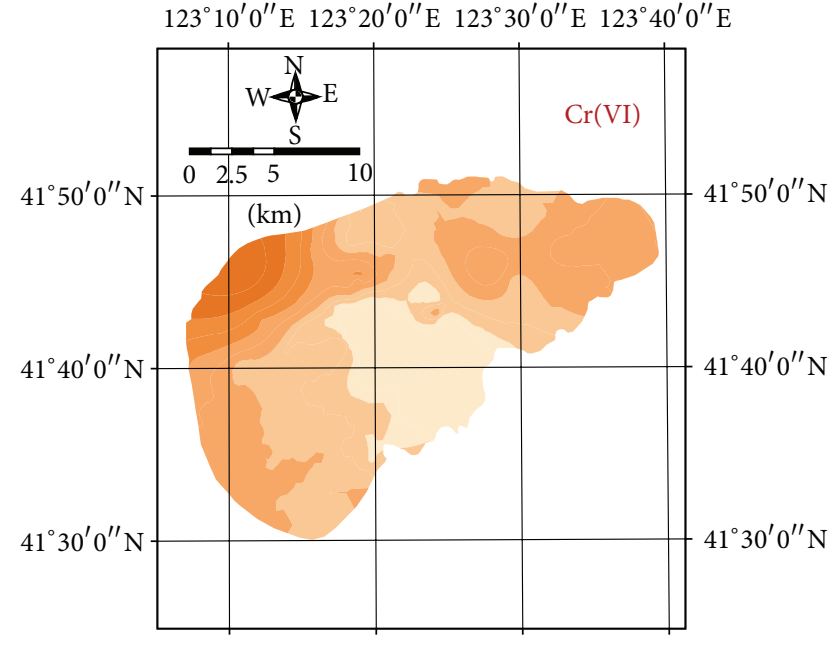

$123^{\circ} 10^{\prime} 0^{\prime \prime} \mathrm{E} 123^{\circ} 20^{\prime} 0^{\prime \prime} \mathrm{E} 123^{\circ} 30^{\prime} 0^{\prime \prime} \mathrm{E} 123^{\circ} 40^{\prime} 0^{\prime \prime} \mathrm{E}$

Concentration (ppb)

$0.040458-0.102019$

$0.102020-0.338209$

$0.338210-0.885032$

$0.885033-2.151020$

$2.151021-5.082000$

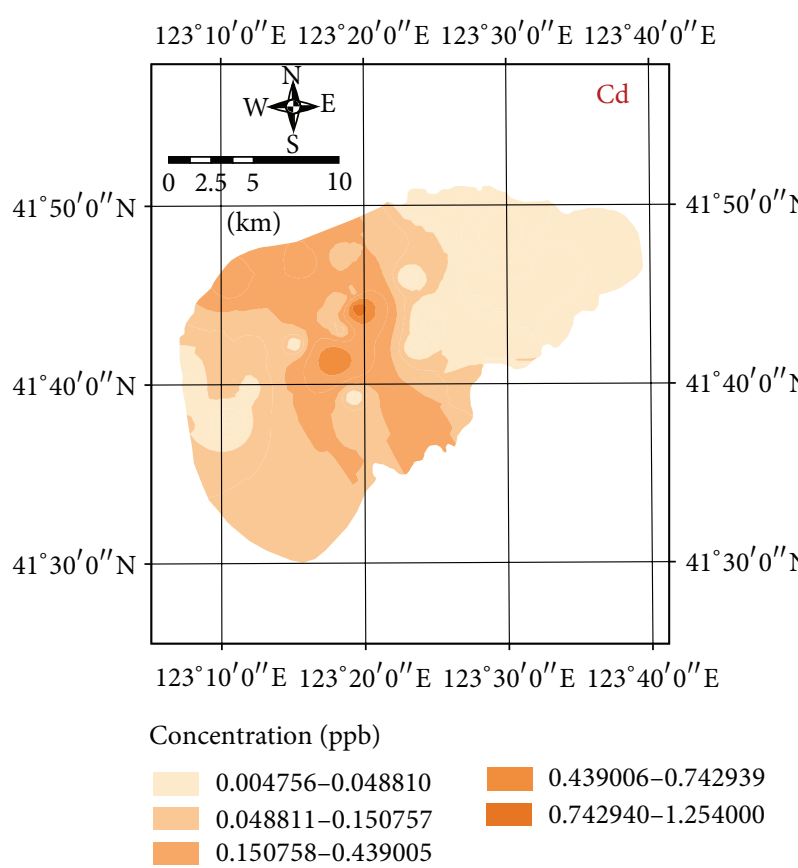

Figure 2: Distributions of $\mathrm{As}, \mathrm{Cr}(\mathrm{VI}), \mathrm{Pb}$, and $\mathrm{Cd}$ contents in groundwater.

contents. The highest As content in the center was $4.25 \mu \mathrm{g} / \mathrm{L}$ in the west polluted area with $1.02 \mathrm{~km}^{2}$; the As content in the second district was $3.5 \mu \mathrm{g} / \mathrm{L}$ with $2.28 \mathrm{~km}^{2}$, followed by the As content being $2.25 \mu \mathrm{g} / \mathrm{L}$ with $23.41 \mathrm{~km}^{2}, 1.5 \mu \mathrm{g} / \mathrm{L}$ with $38.91 \mathrm{~km}^{2}$, and $1.0 \mu \mathrm{g} / \mathrm{L}$ with $286.28 \mathrm{~km}^{2}$, respectively. The contents and the areas after As transfer in different years were showed in Table 2. The results showed that the polluted areas were decreased gradually for the 10 -year transfer in low content districts and decreased gradually for first 5year transfer and increased gradually for last 5-year transfer in high content districts. After 10 years of transfer, the As polluted areas were $2.25 \mathrm{~km}^{2}$ with $4.25 \mu \mathrm{g} / \mathrm{L}, 12.63 \mathrm{~km}^{2}$ with $3.5 \mu \mathrm{g} / \mathrm{L}, 24.22 \mathrm{~km}^{2}$ with $2.25 \mu \mathrm{g} / \mathrm{L}, 36.13 \mathrm{~km}^{2}$ with $1.5 \mu \mathrm{g} / \mathrm{L}$, and $119.30 \mathrm{~km}^{2}$ with $1.0 \mu \mathrm{g} / \mathrm{L}$, respectively. The reason why the As polluted areas were increased in high content districts because these were some pump wells downstream, which 
TABLE 2: Distribution area of As at different concentration ranges in different years.

\begin{tabular}{lccccc}
\hline Time (year) & \multicolumn{3}{c}{ Distribution area $\left(\mathrm{km}^{2}\right)$} & $C>3.5 \mu \mathrm{g} / \mathrm{L}$ & $C>4.25 \mu \mathrm{g} / \mathrm{L}$ \\
\hline 0 & $C>1.0 \mu \mathrm{g} / \mathrm{L}$ & $C>1.5 \mu \mathrm{g} / \mathrm{L}$ & $C>2.25 \mu \mathrm{g} / \mathrm{L}$ & 2.28 & 2.47 \\
1 & 286.28 & 38.91 & 24.41 & 2.66 & 02 \\
2 & 229.15 & 41.12 & 25.46 & 6.10 & 0.96 \\
3 & 210.34 & 42.04 & 26.29 & 10.44 & 0.95 \\
5 & 187.49 & 42.27 & 26.52 & 13.60 & 2.74 \\
10 & 177.79 & 42.46 & 24.23 & & 2.28 \\
\hline
\end{tabular}

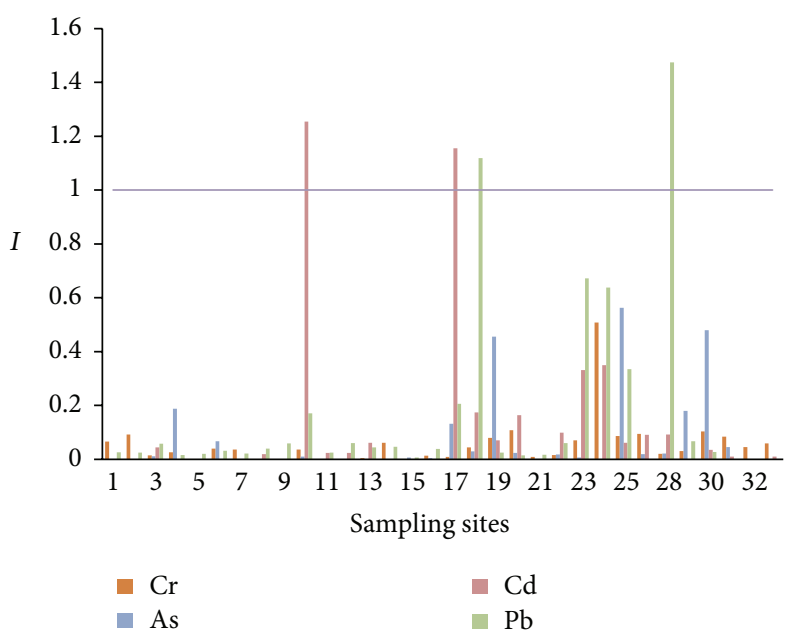

FIGURE 3: Single-factor pollution indices of heavy metals at all groundwater sampling sites.

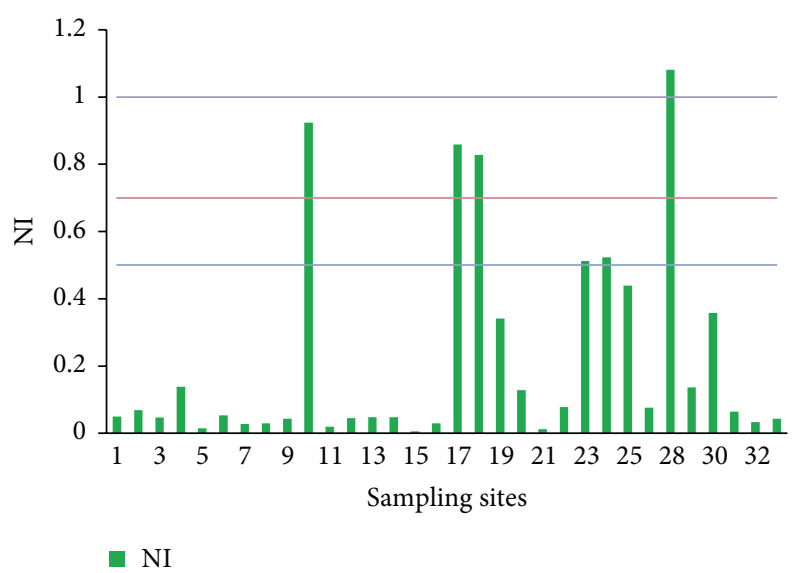

FIGURE 4: NIs of heavy metals at all groundwater sampling sites.

pumped about $2000 \mathrm{~m}^{3} / \mathrm{d}$ each well and made the solute transfer upstream because of the funnels formed.

3.3.2. Simulation of Solute Transport with Addition of Pollution Sources. Into the severely polluted areas, a continuous pollution source with constant pollution concentration was added and the solute transfer was simulated. The simulated results were showed in Figure 6.

With the addition of a pollution source, the simulated results showed that As transfer areas did not change largely from those under the initial conditions; the As polluted area was $286.28 \mathrm{~km}^{2}$ in the west of the study area at the moment. 


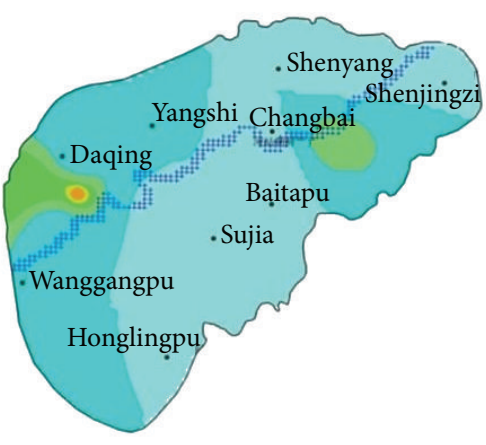

Concentration of As $(\mu \mathrm{g} / \mathrm{L})$

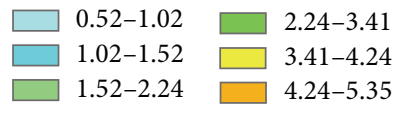

(a)

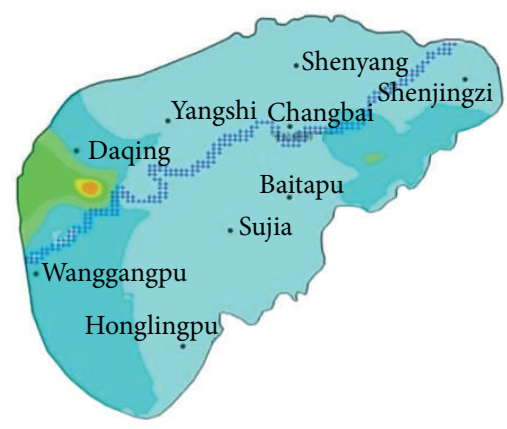

Concentration of As $(\mu \mathrm{g} / \mathrm{L})$

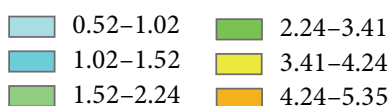

(d)

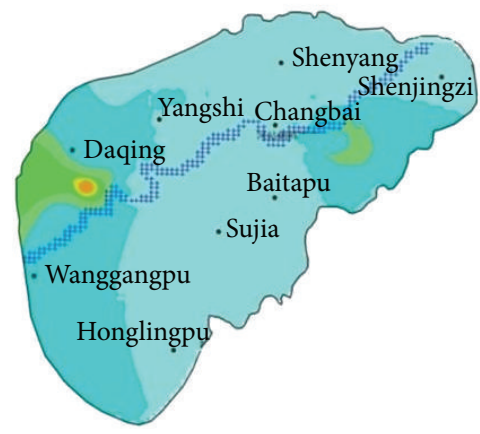

Concentration of As $(\mu \mathrm{g} / \mathrm{L})$

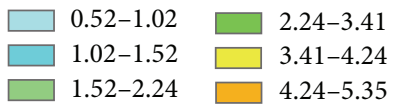

(b)

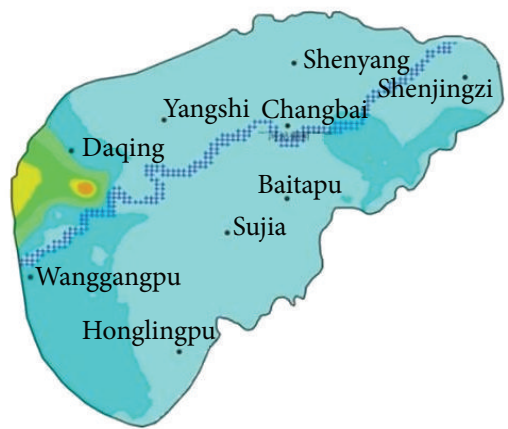

Concentration of As $(\mu \mathrm{g} / \mathrm{L})$

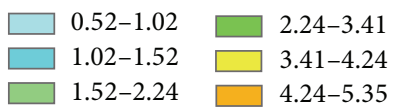

(e)

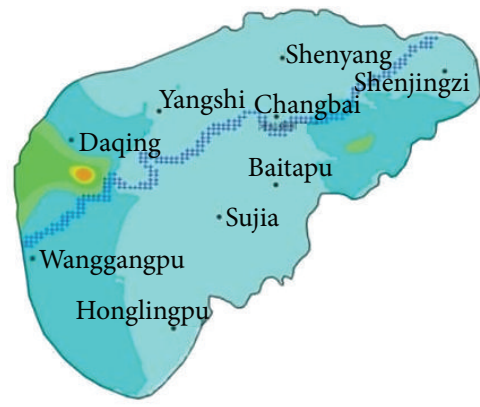

Concentration of As $(\mu \mathrm{g} / \mathrm{L})$

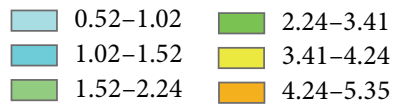

(c)

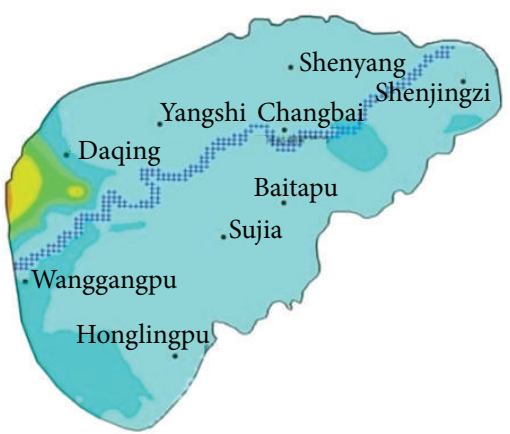

Concentration of As $(\mu \mathrm{g} / \mathrm{L})$

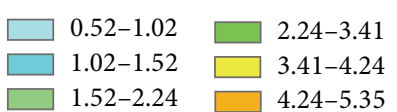

(f)

Figure 5: Diffusion and transport of As in shallow aquifer. (a) Distribution of initial content; (b) after 1 year; (c) after 2 years; (d) after 3 years; (e) after 5 years; (f) after 10 years.

TABLE 3: Distribution area of As at different concentration ranges in different years with addition of a pollution source.

\begin{tabular}{lccccc}
\hline Time (year) & \multicolumn{3}{c}{ Distribution area $\left(\mathrm{km}^{2}\right)$} & $C>3.5 \mu \mathrm{g} / \mathrm{L}$ & $C>4.25 \mu \mathrm{g} / \mathrm{L}$ \\
\hline 0 & $C>1.0 \mu \mathrm{g} / \mathrm{L}$ & $C>1.5 \mu \mathrm{g} / \mathrm{L}$ & $C>2.25 \mu \mathrm{g} / \mathrm{L}$ & 24.88 & 4.63 \\
1 & 295.09 & 42.04 & 25.69 & 4.76 & 3.84 \\
2 & 242.75 & 43.21 & 26.53 & 3.51 & 3.89 \\
3 & 220.01 & 44.06 & 27.52 & 13.38 & 3.99 \\
5 & 212.73 & 45.01 & 30.65 & 14.24 & 3.77 \\
10 & 228.14 & 50.28 & 27.31 & 3.23 \\
\hline
\end{tabular}

The highest As content in the center was $4.25 \mu \mathrm{g} / \mathrm{L}$ in the west polluted area with $3.82 \mathrm{~km}^{2}, 3.5 \mu \mathrm{g} / \mathrm{L}$ with $4.63 \mathrm{~km}^{2}, 2.25 \mu \mathrm{g} / \mathrm{L}$ with $24.88 \mathrm{~km}^{2}, 1.5 \mu \mathrm{g} / \mathrm{L}$ with $42.04 \mathrm{~km}^{2}$, and $1.0 \mu \mathrm{g} / \mathrm{L}$ with 295.09, respectively. The contents and the areas after As transfer in different years were showed in Table 3. The results showed that the changing trend of polluted areas was almost the same with those as initial conditions. However, the highest As content area was not changed almost because of the addition of a pollution source. After 10 years of transfer, the As polluted areas were $3.23 \mathrm{~km}^{2}$ with $4.25 \mu \mathrm{g} / \mathrm{L}$, 

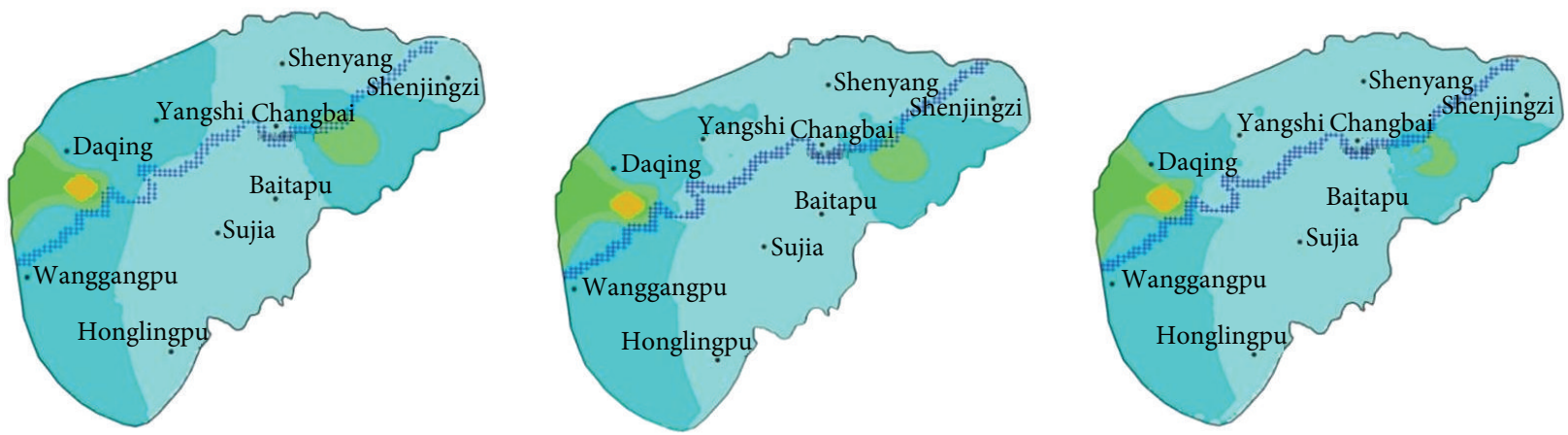

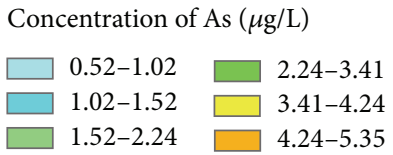

(a)

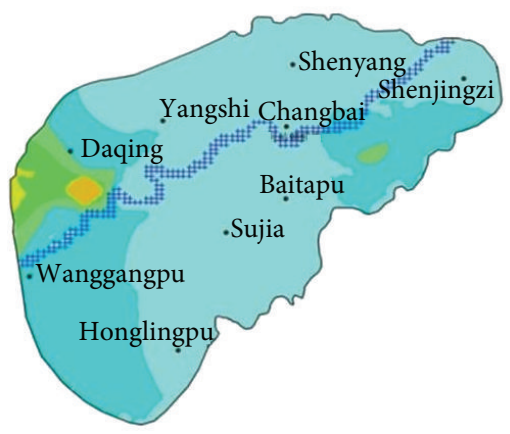

Concentration of As $(\mu \mathrm{g} / \mathrm{L})$

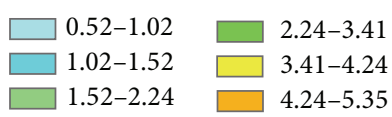

(d)

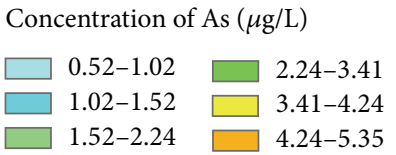

(b)

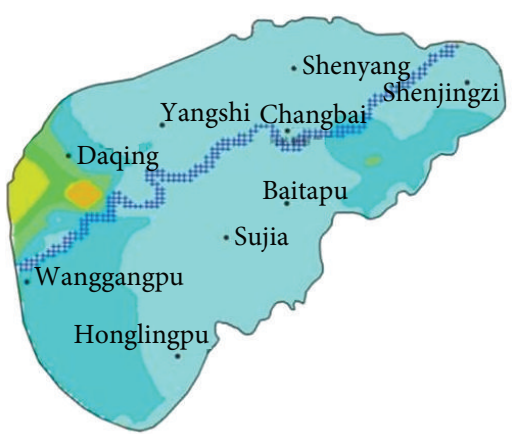

Concentration of As $(\mu \mathrm{g} / \mathrm{L})$

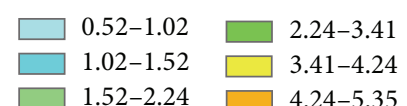

(e)

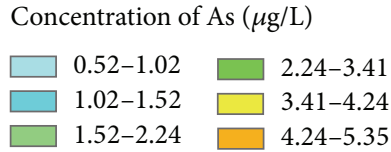

(c)

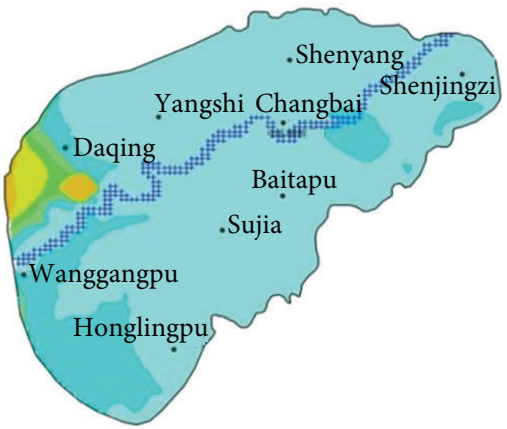

Concentration of As $(\mu \mathrm{g} / \mathrm{L})$

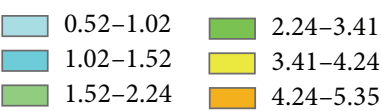

(f)

Figure 6: Diffusion and transport of As in shallow aquifer with addition of a pollution source. (a) Distribution of initial content; (b) after 1 year; (c) after 2 years; (d) after 3 years; (e) after 5 years; (f) after 10 years.

$14.24 \mathrm{~km}^{2}$ with $3.5 \mu \mathrm{g} / \mathrm{L}, 27.31 \mathrm{~km}^{2}$ with $2.25 \mu \mathrm{g} / \mathrm{L}, 35.94 \mathrm{~km}^{2}$ with $1.5 \mu \mathrm{g} / \mathrm{L}$, and $135.80 \mathrm{~km}^{2}$ with $1.0 \mu \mathrm{g} / \mathrm{L}$, respectively.

\section{Risk Assessment of Heavy Metal Pollution in Sediments}

4.1. Contents of Heavy Metals in Sediment. Sediment is a key place in the water suitable for accumulation of heavy metals. The contents of heavy metals in sediment reflect the degree of heavy metal pollution in the water. To clarify the sources of heavy metals in groundwater, we also collected sediment at varying depth. The contents of $\mathrm{Cr}(\mathrm{VI}), \mathrm{As}, \mathrm{Cd}$, and $\mathrm{Pb}$ were measured using ICP-MS. The results are showed in Table 4.

Clearly, Cr pollution was the most severe in sediment of Hun River, and the $\mathrm{Cr}$ contents in most samples exceeded the background value, followed by $\mathrm{Pb}$. Cd content only at site N21-2 exceeded the background value, and no As content exceeded the background value.

\subsection{Risk Assessment of Heavy Metal Pollution in Sediments}

4.2.1. Risk Assessment of Pollution Degree. Single-factor pollution index $C_{f}^{i}$ is expressed as follows:

$$
C_{f}^{i}=\frac{C_{D}^{i}}{C_{R}^{i}},
$$

where $C_{D}^{i}$ is the measured heavy metal content in sediment and $C_{R}^{i}$ is the background content of a heavy metal (Table 4). 
TABLE 4: Contents of heavy metals in sediment of Hun River (ppm).

\begin{tabular}{|c|c|c|c|c|c|}
\hline Number & Thickness $(\mathrm{cm})$ & $\mathrm{Cr}(\mathrm{VI})$ & As & $\mathrm{Cd}$ & $\mathrm{Pb}$ \\
\hline N10-1 & $0-26$ & $62.58 \pm 0.04$ & $3.51 \pm 0.13$ & $0.12 \pm 0.03$ & $15.29 \pm 0.12$ \\
\hline N10-2 & $26-40$ & $47.16 \pm 0.06$ & $2.26 \pm 0.12$ & $0.04 \pm 0.02$ & $12.48 \pm 0.10$ \\
\hline N11-1 & $0-25$ & $114.10 \pm 0.02$ & $7.15 \pm 0.16$ & $0.25 \pm 0.04$ & $37.47 \pm 0.09$ \\
\hline N11-2 & $25-45$ & $98.22 \pm 0.10$ & $5.56 \pm 0.06$ & $0.20 \pm 0.06$ & $29.85 \pm 0.16$ \\
\hline N11-3 & $45-50$ & $60.41 \pm 0.11$ & $3.92 \pm 0.05$ & $0.12 \pm 0.04$ & $21.45 \pm 0.12$ \\
\hline N12-1 & $0-50$ & $147.30 \pm 0.08$ & $4.71 \pm 0.07$ & $0.31 \pm 0.06$ & $77.98 \pm 0.13$ \\
\hline N13-1-1 & $0-5$ & $90.11 \pm 0.06$ & $4.93 \pm 0.07$ & $0.18 \pm 0.03$ & $33.43 \pm 0.11$ \\
\hline N13-1-2 & $5-30$ & $21.93 \pm 0.02$ & $1.46 \pm 0.11$ & $0.02 \pm 0.02$ & $11.14 \pm 0.17$ \\
\hline N13-2-1 & $0-15$ & $68.71 \pm 0.05$ & $4.25 \pm 0.08$ & $0.20 \pm 0.04$ & $21.90 \pm 0.05$ \\
\hline N13-2-2 & $15-40$ & $111.30 \pm 0.11$ & $7.61 \pm 0.07$ & $0.18 \pm 0.06$ & $30.26 \pm 0.06$ \\
\hline N13-2-3 & $40-64$ & $111.10 \pm 0.09$ & $6.11 \pm 0.04$ & $0.29 \pm 0.08$ & $30.43 \pm 0.10$ \\
\hline N14-1 & $0-23$ & $70.67 \pm 0.05$ & $5.02 \pm 0.05$ & $0.20 \pm 0.04$ & $19.53 \pm 0.06$ \\
\hline N14-2 & $23-30$ & $77.33 \pm 0.12$ & $6.14 \pm 0.08$ & $0.18 \pm 0.06$ & $23.94 \pm 0.08$ \\
\hline N14-3 & $30-40$ & $105.50 \pm 0.11$ & $8.36 \pm 0.08$ & $0.28 \pm 0.08$ & $40.66 \pm 0.11$ \\
\hline N14-4 & $40-50$ & $39.99 \pm 0.08$ & $3.45 \pm 0.07$ & $0.11 \pm 0.08$ & $14.68 \pm 0.05$ \\
\hline N16-1 & $0-26$ & $60.38 \pm 0.04$ & $3.65 \pm 0.06$ & $0.14 \pm 0.07$ & $19.98 \pm 0.05$ \\
\hline $\mathrm{N} 16-2$ & $26-50$ & $58.30 \pm 0.06$ & $3.92 \pm 0.06$ & $0.09 \pm 0.07$ & $20.92 \pm 0.07$ \\
\hline N17 & $0-32$ & $58.03 \pm 0.04$ & $1.87 \pm 0.03$ & $0.06 \pm 0.05$ & $15.06 \pm 0.07$ \\
\hline N18 & $0-28$ & $113.70 \pm 0.09$ & $3.86 \pm 0.11$ & $0.18 \pm 0.06$ & $45.28 \pm 0.07$ \\
\hline N19-1 & $0-5$ & $87.94 \pm 0.11$ & $2.80 \pm 0.05$ & $0.28 \pm 0.07$ & $19.42 \pm 0.06$ \\
\hline N19-2 & $5-25$ & $141.40 \pm 0.10$ & $6.55 \pm 0.06$ & $0.28 \pm 0.11$ & $61.48 \pm 0.11$ \\
\hline N20-1 & $0-29$ & $116.50 \pm 0.13$ & $3.89 \pm 0.04$ & $0.33 \pm 0.14$ & $42.30 \pm 0.10$ \\
\hline N21-1 & $0-5$ & $97.22 \pm 0.04$ & $4.40 \pm 0.03$ & $0.20 \pm 0.07$ & $58.54 \pm 0.07$ \\
\hline N21-2 & $5-26$ & $197.80 \pm 0.09$ & $12.84 \pm 0.07$ & $0.64 \pm 0.04$ & $142.60 \pm 0.14$ \\
\hline N24-1 & Surface layer & $35.64 \pm 0.04$ & $2.32 \pm 0.02$ & $0.07 \pm 0.05$ & $15.65 \pm 0.05$ \\
\hline S14-1 & Surface layer & $74.07 \pm 0.05$ & $4.69 \pm 0.04$ & $0.15 \pm 0.08$ & $24.43 \pm 0.06$ \\
\hline S16-1 & Surface layer & $17.23 \pm 0.03$ & $1.17 \pm 0.02$ & $0.03 \pm 0.03$ & $9.46 \pm 0.05$ \\
\hline S19-1 & $0-44$ & $86.18 \pm 0.07$ & $11.61 \pm 0.06$ & $0.19 \pm 0.05$ & $35.57 \pm 0.08$ \\
\hline S19-2 & $0-44$ & $83.73 \pm 0.08$ & $12.21 \pm 0.05$ & $0.21 \pm 0.05$ & $27.86 \pm 0.09$ \\
\hline S20-1 & $0-13$ & $150.20 \pm 0.11$ & $6.97 \pm 0.06$ & $0.38 \pm 0.08$ & $71.41 \pm 0.07$ \\
\hline S20-2 & $13-22$ & $73.72 \pm 0.08$ & $4.21 \pm 0.06$ & $0.10 \pm 0.07$ & $26.27 \pm 0.14$ \\
\hline Background value & & 60 & 15 & 0.5 & 35 \\
\hline
\end{tabular}

Note: the data are the mean \pm standard deviation.

$C_{f}^{i}>1$ indicates "pollution" of a heavy metal, and $C_{f}^{i}<1$ indicates a "clean" state (Table 5).

Compound pollution index (CPI) was used to assess the heavy metal pollution in sediment, which is expressed as follows:

$$
\mathrm{CPI}=\sum_{i=1}^{m} \frac{C_{f}^{i}}{m},
$$

where $C_{f}^{i}$ is a single-factor index of a heavy metal and $m$ is the number of heavy metal types. CPI $<1$ indicates no heavy metal pollution in sediment; CPI $\geq 1$ indicates heavy metal pollution. The results were showed in Table 5.

The pollution levels of the heavy metal were clarified in Table 6. Based on these results, we can see that $\mathrm{Cr}$ pollution was the most severe in the river sediment, and the $\mathrm{Cr}$ contents in most sampling sites exceeded the background value, followed by $\mathrm{Pb}$ (Tables 5-6). Cd content only at site N21-2 exceeded the background value, and no As content exceeded the background value. The sampling sites N12-1, N19-2, N21-2, and S20-1 were at comprehensive pollution, and in particular, the CPI of N21-2 was 2.1716.

4.2.2. Risk Assessment of Heavy Metal Potential Ecological Risks in Sediment. The potential ecological risk index of a heavy metal, $E_{r}^{i}$, is expressed as follows [20]:

$$
E_{r}^{i}=T_{r}^{i} \times C_{f}^{i}
$$


TABLE 5: Assessment of heavy metal pollution degree risks in sediment.

\begin{tabular}{|c|c|c|c|c|c|c|}
\hline \multirow{2}{*}{ Number } & \multirow{2}{*}{ Thickness $(\mathrm{cm})$} & \multicolumn{4}{|c|}{$C_{f}^{i}$} & \multirow{2}{*}{ CPI } \\
\hline & & $C_{f}^{\mathrm{Cr}}$ & $C_{f}^{\text {As }}$ & $C_{f}^{\mathrm{Cd}}$ & $C_{f}^{\mathrm{Pb}}$ & \\
\hline N10-1 & $0-26$ & 0.78 & 0.23 & 0.24 & 0.44 & 0.42 \\
\hline N10-2 & $26-40$ & 0.59 & 0.15 & 0.07 & 0.36 & 0.29 \\
\hline N11-1 & $0-25$ & 1.43 & 0.48 & 0.51 & 1.07 & 0.87 \\
\hline N11-2 & $25-45$ & 1.23 & 0.37 & 0.40 & 0.85 & 0.71 \\
\hline N11-3 & $45-50$ & 0.76 & 0.26 & 0.24 & 0.61 & 0.47 \\
\hline N12-1 & $0-50$ & 1.84 & 0.31 & 0.62 & 2.23 & 1.25 \\
\hline N13-1-1 & $0-5$ & 1.13 & 0.33 & 0.36 & 0.96 & 0.69 \\
\hline N13-1-2 & $5-30$ & 0.27 & 0.10 & 0.05 & 0.32 & 0.18 \\
\hline N13-2-1 & $0-15$ & 0.86 & 0.28 & 0.39 & 0.63 & 0.54 \\
\hline N13-2-2 & $15-40$ & 1.39 & 0.51 & 0.37 & 0.87 & 0.78 \\
\hline N13-2-3 & $40-64$ & 1.39 & 0.41 & 0.59 & 0.87 & 0.81 \\
\hline N14-1 & $0-23$ & 0.88 & 0.34 & 0.40 & 0.56 & 0.54 \\
\hline N14-2 & $23-30$ & 0.97 & 0.41 & 0.36 & 0.68 & 0.61 \\
\hline N14-3 & $30-40$ & 1.32 & 0.56 & 0.56 & 1.16 & 0.90 \\
\hline N14-4 & $40-50$ & 0.50 & 0.23 & 0.23 & 0.42 & 0.34 \\
\hline N16-1 & $0-26$ & 0.76 & 0.24 & 0.27 & 0.57 & 0.46 \\
\hline N16-2 & $26-50$ & 0.73 & 0.26 & 0.18 & 0.60 & 0.44 \\
\hline N17 & $0-32$ & 0.73 & 0.13 & 0.11 & 0.43 & 0.35 \\
\hline N18 & $0-28$ & 1.42 & 0.26 & 0.35 & 1.29 & 0.83 \\
\hline N19-1 & $0-5$ & 1.10 & 0.19 & 0.57 & 0.56 & 0.60 \\
\hline N19-2 & $5-25$ & 1.77 & 0.44 & 0.56 & 1.76 & 1.13 \\
\hline N20-1 & $0-29$ & 1.46 & 0.26 & 0.67 & 1.21 & 0.90 \\
\hline N21-1 & $0-5$ & 1.22 & 0.29 & 0.40 & 1.67 & 0.90 \\
\hline N21-2 & $5-26$ & 2.47 & 0.86 & 1.28 & 4.07 & 2.17 \\
\hline N24-1 & Surface layer & 0.45 & 0.15 & 0.14 & 0.45 & 0.30 \\
\hline S14-1 & Surface layer & 0.93 & 0.31 & 0.31 & 0.70 & 0.56 \\
\hline S16-1 & Surface layer & 0.22 & 0.08 & 0.05 & 0.27 & 0.15 \\
\hline S19-1 & $0-44$ & 1.08 & 0.77 & 0.38 & 1.02 & 0.81 \\
\hline S19-2 & $0-44$ & 1.05 & 0.81 & 0.42 & 0.80 & 0.77 \\
\hline S20-1 & $0-13$ & 1.88 & 0.46 & 0.77 & 2.04 & 1.29 \\
\hline S20-2 & $13-22$ & 0.92 & 0.28 & 0.21 & 0.75 & 0.54 \\
\hline
\end{tabular}

where $T_{r}^{i}$ is the toxicity response coefficient of that heavy metal and reflects the toxicity of the heavy metal and the water body's sensitivity to the heavy metal pollution; $C_{f}^{i}$ is the coefficient of pollution.

The potential ecological risk index of multiple heavy metal (RI) is expressed as follows [20]:

$$
\mathrm{RI}=\sum_{i=1}^{m} E_{r}^{i}
$$

The ecological risk of the study area was assessed using the classification of all potential ecological risk indices (Table 7).

Clearly, $E_{r}^{i}$ of four heavy metals was $<40$, indicating the four heavy metals were at low potential ecological risks. The RI at site N21-2 was 40-80, indicating severe risk. The other sampling sites were at low potential ecological risks.
TABLE 6: Heavy metal pollution levels.

\begin{tabular}{lccccc}
\hline \multirow{2}{*}{ Number } & \multicolumn{5}{c}{ Pollution level } \\
& $\mathrm{Cr}$ & As & $\mathrm{Cd}$ & $\mathrm{Pb}$ & Comparison \\
\hline N11-1 & Polluted & - & - & Polluted & $\mathrm{Cr}>\mathrm{Pb}$ \\
N11-2 & Polluted & - & - & - & \\
N12-1 & Polluted & - & - & Polluted & $\mathrm{Cr}>\mathrm{Pb}$ \\
N13-1-1 & Polluted & - & - & Polluted & \\
N13-2-2 & Polluted & - & - & - & \\
N13-2-3 & Polluted & - & - & - & \\
N18 & Polluted & - & - & Polluted & $\mathrm{Cr}>\mathrm{Pb}$ \\
N19-1 & Polluted & - & - & - & \\
N19-2 & Polluted & - & - & Polluted & $\mathrm{Cr}>\mathrm{Pb}$ \\
N20-1 & Polluted & - & - & Polluted & $\mathrm{Cr}>\mathrm{Pb}$ \\
N21-1 & Polluted & - & - & Polluted & $\mathrm{Cr}>\mathrm{Pb}$ \\
N21-2 & Polluted & - & Polluted & Polluted & $\mathrm{Pb}>\mathrm{Cr}>\mathrm{Cd}$ \\
S19-1 & Polluted & - & - & Polluted & $\mathrm{Cr}>\mathrm{Pb}$ \\
S19-2 & Polluted & - & - & - & \\
S20-1 & Polluted & - & - & Polluted & $\mathrm{Pb}>\mathrm{Cr}$ \\
\hline
\end{tabular}

TABLE 7: Assessment of heavy metal potential ecological risks in sediment.

\begin{tabular}{lcccccc}
\hline Number & Thickness (cm) & \multicolumn{5}{c}{$E_{r}^{i}$} \\
& & Cr & As & Cd & Pb & RI \\
\hline N10-1 & $0-26$ & 1.18 & 1.50 & 2.20 & 1.78 & 6.67 \\
N10-2 & $26-40$ & 1.56 & 2.34 & 7.10 & 2.18 & 13.19 \\
N11-1 & $0-25$ & 2.85 & 4.77 & 15.25 & 5.35 & 28.23 \\
N11-2 & $25-45$ & 2.46 & 3.70 & 12.11 & 4.26 & 22.54 \\
N11-3 & $45-50$ & 1.51 & 2.61 & 7.08 & 3.06 & 14.27 \\
N12-1 & $0-50$ & 3.68 & 3.14 & 18.59 & 11.14 & 36.55 \\
N12-2 & Surface layer & 2.20 & 3.58 & 9.58 & 3.69 & 19.05 \\
N13-1-1 & $0-5$ & 2.25 & 3.29 & 10.71 & 4.78 & 21.02 \\
N13-1-2 & $5-30$ & 0.55 & 0.98 & 1.41 & 1.59 & 4.53 \\
N13-2-1 & $0-15$ & 1.72 & 2.83 & 11.72 & 3.13 & 19.40 \\
N13-2-2 & $15-40$ & 2.78 & 5.07 & 10.96 & 4.32 & 23.14 \\
N13-2-3 & $40-64$ & 2.78 & 4.08 & 17.55 & 4.35 & 28.75 \\
N14-1 & $0-23$ & 1.77 & 3.35 & 11.99 & 2.79 & 19.90 \\
N14-2 & $23-30$ & 1.93 & 4.09 & 10.78 & 3.42 & 20.22 \\
N14-3 & $30-40$ & 2.64 & 5.57 & 16.70 & 5.81 & 30.72 \\
N14-4 & $40-50$ & 1.00 & 2.30 & 6.79 & 2.10 & 12.19 \\
N16-1 & $0-26$ & 1.51 & 2.43 & 8.12 & 2.85 & 14.92 \\
N16-2 & $26-50$ & 1.46 & 2.61 & 5.31 & 2.99 & 12.36 \\
N17 & $0-32$ & 1.45 & 1.25 & 3.34 & 2.15 & 8.19 \\
N18 & $0-28$ & 2.84 & 2.57 & 10.55 & 6.47 & 22.43 \\
N19-1 & $0-5$ & 2.20 & 1.86 & 17.09 & 2.77 & 23.93 \\
N19-2 & $5-25$ & 3.54 & 4.36 & 16.85 & 8.78 & 33.53 \\
N20-1 & $0-29$ & 2.91 & 2.60 & 20.02 & 6.04 & 31.57 \\
N21-1 & $0-5$ & 2.43 & 2.94 & 11.94 & 8.36 & 25.67 \\
N21-2 & $5-26$ & 4.95 & 8.56 & 38.51 & 20.37 & 72.39 \\
N24-1 & Surface layer & 0.89 & 1.54 & 4.05 & 2.24 & 8.72 \\
S14-1 & Surface layer & 1.85 & 3.13 & 9.16 & 3.49 & 17.63 \\
S16-1 & Surface layer & 0.43 & 0.78 & 1.63 & 1.35 & 4.19 \\
S19-1 & $0-44$ & 2.15 & 7.74 & 11.51 & 5.08 & 26.49 \\
S19-2 & $0-44$ & 2.09 & 8.14 & 12.62 & 3.98 & 26.84 \\
S20-1 & $0-13$ & 3.76 & 4.64 & 22.97 & 10.20 & 41.57 \\
S20-2 & $13-22$ & 1.84 & 2.80 & 6.25 & 3.75 & 14.65 \\
\hline & & & & & &
\end{tabular}


TABLE 8: Morphologic analysis of heavy metals in sediment.

\begin{tabular}{|c|c|c|c|c|c|c|}
\hline \multirow[b]{2}{*}{ Number } & \multirow[b]{2}{*}{ Heavy metals } & \multicolumn{4}{|c|}{ Proportion of various forms $\%$} & \multirow{2}{*}{$\begin{array}{l}\text { Morphological } \\
\text { distribution } \\
\text { order }\end{array}$} \\
\hline & & $\begin{array}{l}\text { A (weak acid-extractable } \\
\text { form) }\end{array}$ & $\begin{array}{c}\text { B } \\
\text { (reducible form) }\end{array}$ & $\begin{array}{c}\text { C } \\
\text { (oxidizable form) }\end{array}$ & $\begin{array}{c}\mathrm{D} \\
\text { (residual form) }\end{array}$ & \\
\hline \multirow{4}{*}{ N19-2 } & $\mathrm{Cr}(\mathrm{VI})$ & $0.11 \pm 0.09$ & $0.25 \pm 0.17$ & $0.90 \pm 0.32$ & $98.74 \pm 0.36$ & $\mathrm{D}>\mathrm{C}>\mathrm{B}>\mathrm{A}$ \\
\hline & As & $0.66 \pm 0.12$ & $0.91 \pm 0.13$ & $0.33 \pm 0.17$ & $98.10 \pm 0.33$ & $\mathrm{D}>\mathrm{B}>\mathrm{A}>\mathrm{C}$ \\
\hline & $\mathrm{Cd}$ & $6.88 \pm 0.18$ & $2.96 \pm 0.17$ & $1.33 \pm 0.16$ & $88.83 \pm 0.27$ & $\mathrm{D}>\mathrm{A}>\mathrm{B}>\mathrm{C}$ \\
\hline & $\mathrm{Pb}$ & $0.16 \pm 0.11$ & $1.45 \pm 0.26$ & $0.09 \pm 0.08$ & $98.30 \pm 0.36$ & $\mathrm{D}>\mathrm{B}>\mathrm{A}>\mathrm{C}$ \\
\hline \multirow{4}{*}{ S20-1 } & $\mathrm{Cr}(\mathrm{VI})$ & $0.53 \pm 0.21$ & $0.60 \pm 0.24$ & $3.98 \pm 0.27$ & $94.88 \pm 0.55$ & $\mathrm{D}>\mathrm{C}>\mathrm{B}>\mathrm{A}$ \\
\hline & As & $0.76 \pm 0.23$ & $1.56 \pm 0.21$ & $0.64 \pm 0.21$ & $97.04 \pm 0.30$ & $\mathrm{D}>\mathrm{B}>\mathrm{A}>\mathrm{C}$ \\
\hline & $\mathrm{Cd}$ & $5.85 \pm 0.19$ & $2.89 \pm 0.17$ & $0.70 \pm 0.33$ & $90.56 \pm 0.26$ & $\mathrm{D}>\mathrm{A}>\mathrm{B}>\mathrm{C}$ \\
\hline & $\mathrm{Pb}$ & $0.12 \pm 0.08$ & $1.60 \pm 0.32$ & $0.10 \pm 0.08$ & $98.18 \pm 0.41$ & $\mathrm{D}>\mathrm{B}>\mathrm{A}>\mathrm{C}$ \\
\hline \multirow{4}{*}{ N21-1 } & $\mathrm{Cr}(\mathrm{VI})$ & $0.15 \pm 0.10$ & $0.38 \pm 0.21$ & $2.62 \pm 0.14$ & $96.85 \pm 0.27$ & $\mathrm{D}>\mathrm{C}>\mathrm{B}>\mathrm{A}$ \\
\hline & As & $1.22 \pm 0.14$ & $0.95 \pm 0.27$ & $0.54 \pm 0.17$ & $97.28 \pm 0.11$ & $\mathrm{D}>\mathrm{A}>\mathrm{B}>\mathrm{C}$ \\
\hline & $\mathrm{Cd}$ & $22.74 \pm 0.19$ & $3.32 \pm 0.33$ & $1.34 \pm 0.22$ & $72.60 \pm 0.12$ & $\mathrm{D}>\mathrm{A}>\mathrm{B}>\mathrm{C}$ \\
\hline & $\mathrm{Pb}$ & $0.28 \pm 0.11$ & $2.30 \pm 0.15$ & $0.25 \pm 0.19$ & $97.17 \pm 0.16$ & $\mathrm{D}>\mathrm{B}>\mathrm{A}>\mathrm{C}$ \\
\hline \multirow{4}{*}{$\mathrm{N} 21-2$} & $\mathrm{Cr}(\mathrm{VI})$ & $0.08 \pm 0.06$ & $0.31 \pm 0.12$ & $0.75 \pm 0.33$ & $98.86 \pm 0.27$ & $\mathrm{D}>\mathrm{C}>\mathrm{B}>\mathrm{A}$ \\
\hline & As & $0.47 \pm 0.21$ & $1.07 \pm 0.20$ & $0.66 \pm 0.25$ & $97.80 \pm 0.20$ & $\mathrm{D}>\mathrm{B}>\mathrm{C}>\mathrm{A}$ \\
\hline & $\mathrm{Cd}$ & $5.49 \pm 0.25$ & $3.53 \pm 0.25$ & $4.97 \pm 0.29$ & $86.01 \pm 0.11$ & $\mathrm{D}>\mathrm{A}>\mathrm{C}>\mathrm{B}$ \\
\hline & $\mathrm{Pb}$ & $0.12 \pm 0.08$ & $1.74 \pm 0.23$ & $0.38 \pm 0.16$ & $97.77 \pm 0.29$ & $\mathrm{D}>\mathrm{B}>\mathrm{C}>\mathrm{A}$ \\
\hline
\end{tabular}

Note: the data are the mean \pm standard deviation.

4.3. Morphologic Analysis of Heavy Metals in Sediment. The major states of heavy metals include weak acid-extractable form, reducible form, oxidizable form, and residual form [22]. We analyzed the forms of heavy metals at the severely polluted sites (N19-2, S20-1, N21-1, and N21-2) according to Soil and Sediment-Sequential Extraction Procedure of Speciation of 13 Trace Elements (GB/T25282-2010). The results are showed in Table 8.

Clearly, the proportions of bioavailability forms of Cd were all the highest among the four metals at four sites, especially the weak acid-extractable form. The forms indicate that $\mathrm{Cd}$ is most soluble in rivers and its migration features facilitate its migration via the water into groundwater, which is basically consistent with the heavy metal pollution situations in groundwater described in Section 3.1. Then $\mathrm{Pb}$ was mainly in the reducible form, indicating that $\mathrm{Pb}$ can be easily released into the environment to pollute the water. Therefore, we deduce that the release of heavy metals from sediment is a major pollution source of heavy metals in groundwater.

\section{Conclusions}

(1) The comprehensive pollution at groundwater site 28 reached the pollution level, sites 10,17 , and 18 reached warning level, and other sites were all clean. The changes and migration scope of As content indicate that As migrated downstream to Hun River in recent 10 years; the polluted areas were decreased gradually in low content districts and decreased gradually first and increased gradually later in high content districts because these were some pump wells downstream to form groundwater depression cone, which made the solute transfer upstream.
(2) Both the $\mathrm{Cr}(\mathrm{VI})$ and $\mathrm{Pb}$ contents in most sediment samples exceeded the national background values. The As contents at all sites did not exceed the background value. The potential ecological risk of Cd was very high at site N21-2, but not at other sites.

(3) Through the morphological analysis of heavy metals at four sites where the contents were the highest, the proportions of biodegradable form of $\mathrm{Cd}$ were all the highest among the four metals at four sites, secondly was the weak acid-extractable, which all indicated $\mathrm{Cd}$ could be easily released into the water and polluted the groundwater due to the migration. $\mathrm{Pb}$ was mainly in the reduction form, indicating that $\mathrm{Pb}$ also can be released into the environment and pollute the water. Therefore, we deduce that the release from sediment is a major source of heavy metal pollution in groundwater.

\section{Conflict of Interests}

The authors declare that there is no conflict of interests regarding the publication of this paper.

\section{Acknowledgments}

The present work was funded by National Key Technology R\&D Program (Grant no. 2012BAJ25B10) and National Natural Science Foundation of China (Grant no. 41472214) and also financially supported by Graduate Innovation Fund of Jilin University (no. 2015027). The authors thank the Key Laboratory of Groundwater Resources and Environment, Ministry of Education, Jilin University, for allowing them the use of their facilities. 


\section{References}

[1] J. Fu, X. Hu, X. Tao, H. Yu, and X. Zhang, "Risk and toxicity assessments of heavy metals in sediments and fishes from the Yangtze River and Taihu Lake, China," Chemosphere, vol. 93, no. 9, pp. 1887-1895, 2013.

[2] E. Dimitriou, I. Karaouzas, K. Sarantakos, I. Zacharias, K. Bogdanos, and A. Diapoulis, "Groundwater risk assessment at a heavily industrialised catchment and the associated impacts on a peri-urban wetland," Journal of Environmental Management, vol. 88, no. 3, pp. 526-538, 2008.

[3] J. Yang, L. Chen, L.-Z. Liu, W.-L. Shi, and X.-Z. Meng, "Comprehensive risk assessment of heavy metals in lake sediment from public parks in Shanghai," Ecotoxicology and Environmental Safety, vol. 102, no. 1, pp. 129-135, 2014.

[4] J. Wang, S. Chen, and T. Xia, "Environmental risk assessment of heavy metals in Bohai Sea, North China," Procedia Environmental Sciences, vol. 2, pp. 1632-1642, 2010.

[5] S. Muhammad, M. T. Shah, and S. Khan, "Health risk assessment of heavy metals and their source apportionment in drinking water of Kohistan region, northern Pakistan," Microchemical Journal, vol. 98, no. 2, pp. 334-343, 2011.

[6] L. Liu, J. Lv, G. Xu et al., "Uniformly dispersed CdS nanoparticles sensitized $\mathrm{TiO}_{2}$ nanotube arrays with enhanced visiblelight photocatalytic activity and stability," Journal of Solid State Chemistry, vol. 208, pp. 27-34, 2013.

[7] M. A. Hashim, S. Mukhopadhyay, J. N. Sahu, and B. Sengupta, "Remediation technologies for heavy metal contaminated groundwater," Journal of Environmental Management, vol. 92, no. 10, pp. 2355-2388, 2011.

[8] Y. Li, J. Li, S. Chen, and W. Diao, "Establishing indices for groundwater contamination risk assessment in the vicinity of hazardous waste landfills in China," Environmental Pollution, vol. 165, pp. 77-90, 2012.

[9] X. Zheng, B. Li, B. Zhu et al., "Crayfish carapace micro-powder (CCM): a novel and efficient adsorbent for heavy metal ion removal from wastewater," Water, vol. 2, no. 2, pp. 257-272, 2010.

[10] X. Yuan, L. Zhang, J. Li, C. Wang, and J. Ji, “Sediment properties and heavy metal pollution assessment in the river, estuary and lake environments of a fluvial plain, China," Catena, vol. 119, pp. 52-60, 2014.

[11] H.-N. Zhu, X.-Z. Yuan, G.-M. Zeng et al., "Ecological risk assessment of heavy metals in sediments of Xiawan Port based on modified potential ecological risk index," Transactions of Nonferrous Metals Society of China, vol. 22, no. 6, pp. 1470-1477, 2012.

[12] J. Liu, H. Wu, J. Feng, Z. Li, and G. Lin, "Heavy metal contamination and ecological risk assessments in the sediments and zoobenthos of selected mangrove ecosystems, South China," Catena, vol. 119, pp. 136-142, 2014.

[13] A. Zahra, M. Z. Hashmi, R. N. Malik, and Z. Ahmed, "Enrichment and geo-accumulation of heavy metals and risk assessment of sediments of the Kurang Nallah-feeding tributary of the Rawal Lake Reservoir, Pakistan," Science of the Total Environment, vol. 470-471, pp. 925-933, 2014.

[14] K. H. Chu, X. Feng, E. Y. Kim, and Y. Hung, "Biosorption parameter estimation with genetic algorithm," Water, vol. 3, no. 1, pp. 177-195, 2011.

[15] D. Hou, J. He, C. Lü et al., "Distribution characteristics and potential ecological risk assessment of heavy metals $(\mathrm{Cu}, \mathrm{Pb}$, $\mathrm{Zn}, \mathrm{Cd}$ ) in water and sediments from Lake Dalinouer, China,"
Ecotoxicology and Environmental Safety, vol. 93, pp. 135-144, 2013.

[16] B. E. Bakhshayesh, M. Delkash, and M. Scholz, "Response of vegetables to cadmium-enriched soil," Water, vol. 6, no. 5, pp. 1246-1256, 2014.

[17] L. Zhao, Y. Xu, H. Hou, Y. Shangguan, and F. Li, "Source identification and health risk assessment of metals in urban soils around the Tanggu chemical industrial district, Tianjin, China," Science of the Total Environment, vol. 468-469, pp. 654-662, 2014.

[18] X. Su, H. Wang, and Y. Zhang, "Health risk assessment of nitrate contamination in groundwater: a case study of an agricultural area in northeast China," Water Resources Management, vol. 27, no. 8, pp. 3025-3034, 2013.

[19] Z. Wang, L. Yao, G. Liu, and W. Liu, "Heavy metals in water, sediments and submerged macrophytes in ponds around the Dianchi Lake, China," Ecotoxicology and Environmental Safety, vol. 107, pp. 200-206, 2014.

[20] P. Wang, Z.-Z. Zhao, J.-G. Wang, Z.-W. Zhang, and Z.-C. Zhang, "Distribution characteristic and potential ecological risk assessment of heavy metals in latosol in the Western area of Hainan island," Journal of Anhui Agricultural Sciences, no. 9, pp. 5210-5339, 2011.

[21] J.-J. Li, M.-H. Feng, and L. Yu, "Assessment on the situation of water quality in Liaodong Bay shallow waters," Marine Environmental Science, no. 3, pp. 42-45, 2001.

[22] J. Zhao, G. Ying, D. Wei, and M. Ren, "Ecological risk assessment methodology of toxic pollutants in surface water and sediments: a review," Asian Journal of Ecotoxicology, no. 6, pp. 577-588, 2011 

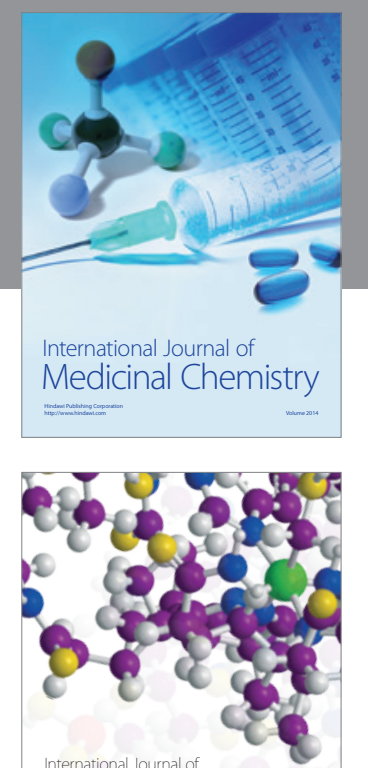

\section{Carbohydrate} Chemistry

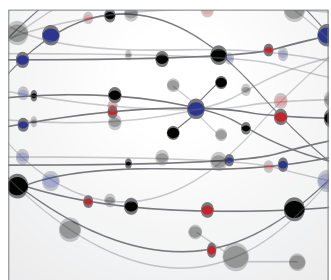

The Scientific World Journal
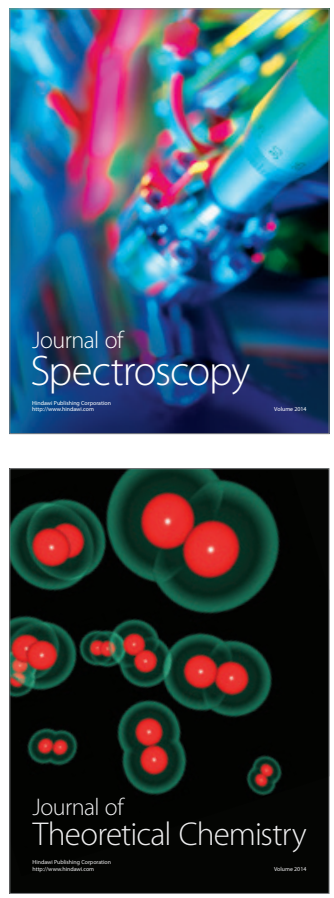
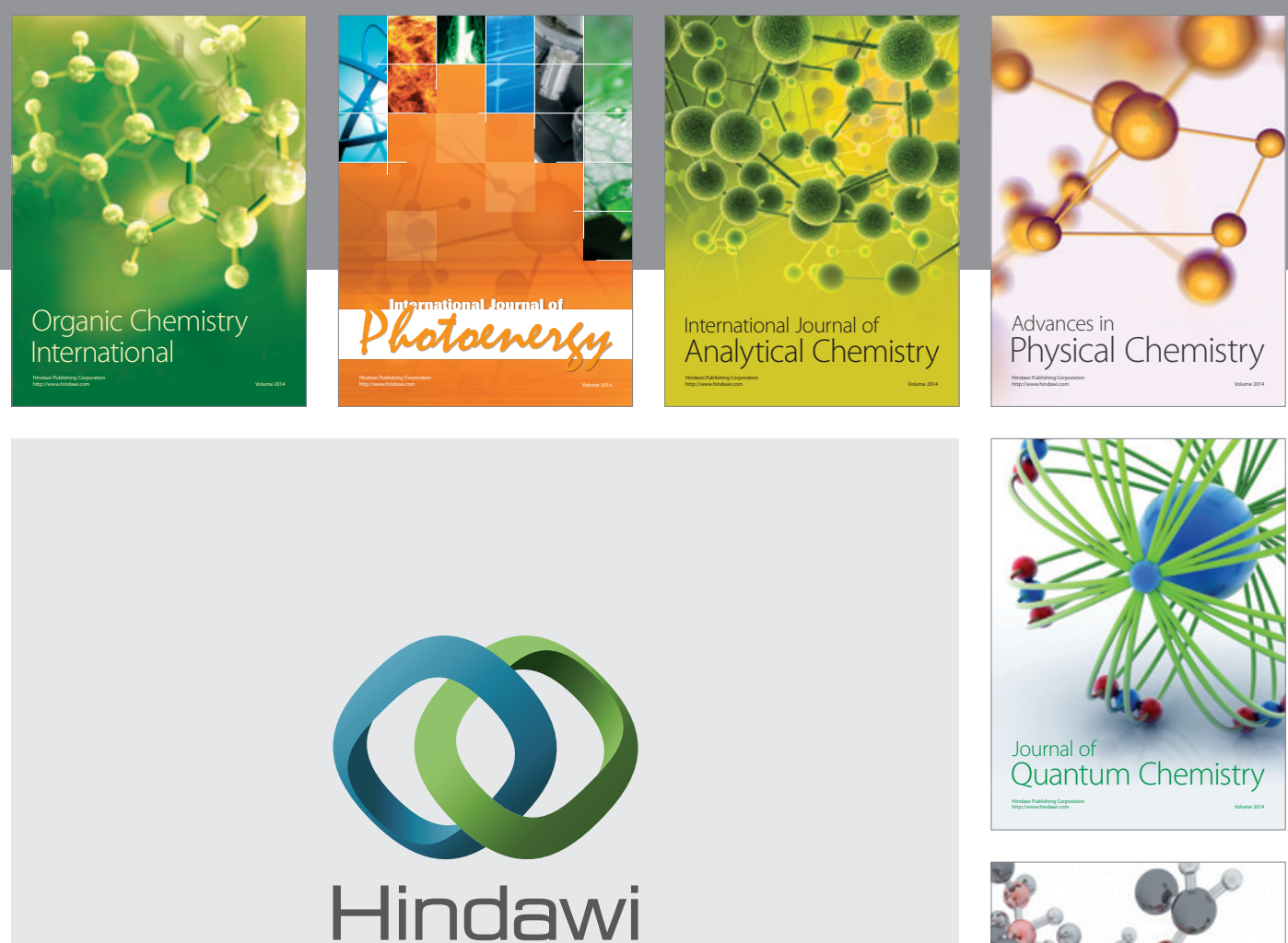

Submit your manuscripts at

http://www.hindawi.com

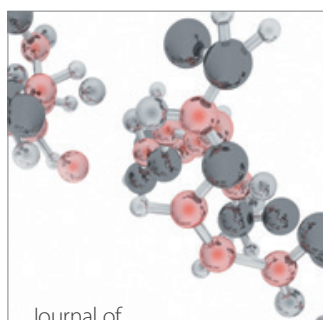

Analytical Methods

in Chemistry

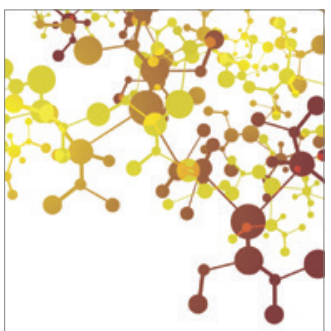

Journal of

Applied Chemistry

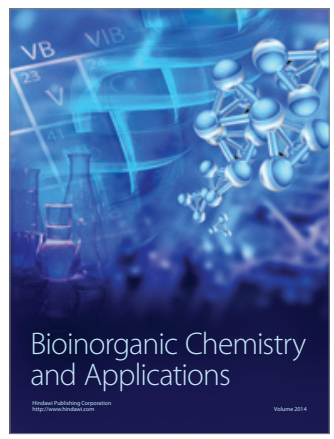

Inorganic Chemistry
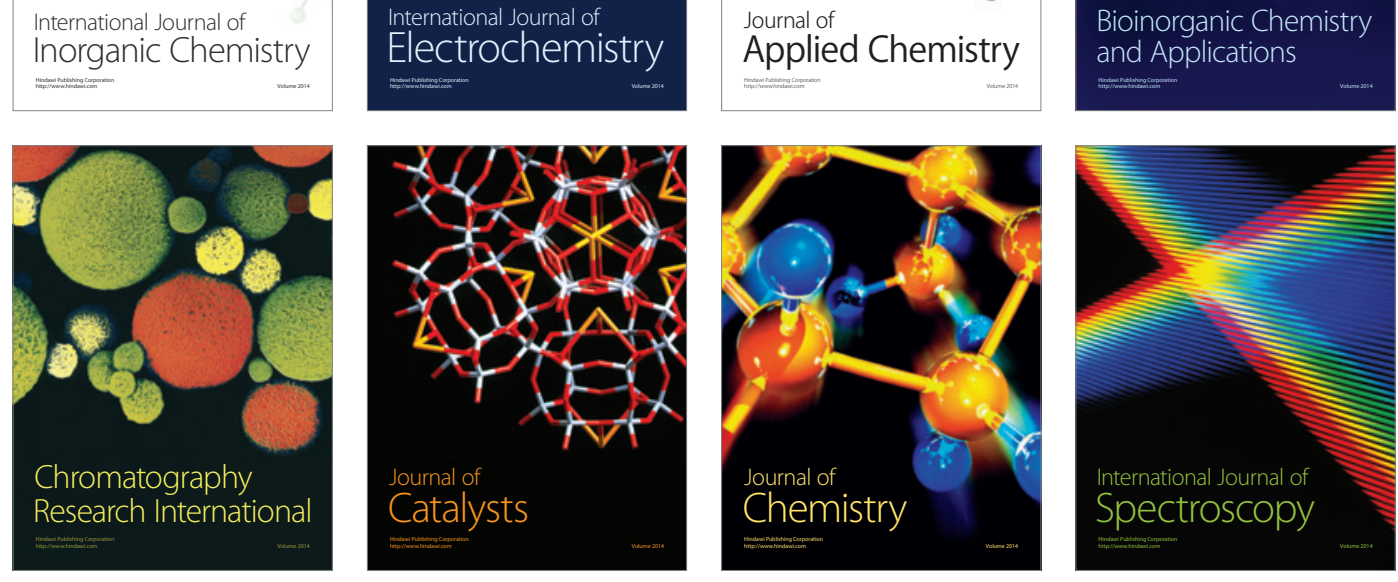